\title{
The Earliest Books at the University of London: A Supplement
}

K.E. Attar

University of London

Published in Library \& Information History, 35 (2019), 40-43.

https://doi.org/10.1080/17583489.2019.1589733

In 2016 I published an article in the pages of this journal reconstructing the donation of the Ilfracombe medical practitioner Nathaniel Vye to the University of London in 1838, the first bulk gift of early printed books to the new University. ${ }^{1}$ The donation had been described as constituting 185 volumes, ${ }^{2}$ several of which were components of multivolume works. My reconstruction comprised 98 titles (including several multivolume works), of which 73 were marked as having been Vye's and 23 could confidently be deduced as having been Vye's. Two further titles were required to complete the list, and three titles from the University of London Library's catalogue seemed plausible candidates. ${ }^{3}$ I noted a margin for error, ${ }^{4}$ and in 2018 a further title which was definitely part of the Vye gift indeed emerged, with the pencilled note 'N. Vye, 1 Vol.' on the verso of the front flyleaf to prove its provenance. The purpose of this note is to describe that volume and its place within the collection in a correction of my former article.

The volume in question is by the classicist, Biblical critic and late-Enlightenment philosopher Hermann Samuel Reimarus (1694-1768), and is the second edition of his Allgemeine Betrachtungen über die Triebe der Thiere, hauptsächlich über ihre Kunsttriebe, zum Erkenntniss des Zusammenhanges der Welt, des Schöpfers und unser selbst (Hamburg: Johann Carl Bohn, 1762). A physico-theological text combating materialism (especially that of his French contemporaries Julien Offray de La Mettrie and Étienne Bonnot de Condillac), it differentiates between mankind and animals by arguing that animals act from God-given instinct, lacking the reason, and the skills acquired by experience and reason, which distinguish humans. Animal drives are divided into ten classes, subdivided into fifty-seven sub-classes. The book is a pioneering work on animal behaviour, the most extensive study of the subject to appear in the eighteenth century and the first critical work to do so. It reflects Reimarus's long-standing interest in the topic, deriving ultimately from a speech he gave as high school rector in Wismar in 1725, and developing the fifth section of his popular Die vornehmsten Wahrheiten der natürlichen Religion (1756), also in Vye's collection. The work was well received until the end of the eighteenth century, with four editions, two translations, and several positive reviews. As a book of its time, it fell out of public consciousness as 
thought moved on. ${ }^{5}$ Copac records only two copies of the second edition apart from one held at the University of London's Senate House Library, with six copies of the third edition (1773) and nine of the fourth (1798).

The Vye copy complements two books by Reimarus from the previous decade in Vye's collection, Die Vernunftlehre, als eine Anweisung zum richtigen Gebrauche der Vernunft in dem Erkenntniss der Wahrheit (1758) and Die vornehmsten Wahrheiten der natürlichen Religion in zehn Abhandlungen, auf eine begreifliche Art erkläret und gerettet (1755). ${ }^{6}$ Both, like Allgemeine Betrachtungen, are second editions, and both, also like Allgemeine Betrachtungen, were published by the well-known Hamburg bookseller and publisher Johann Carl Bohn, who made a name for himself by publishing important writers of the Enlightenment (not least Reimarus). The three volumes were treated as a set, being bound uniformly in contemporary marbled sheep with marbled endpapers and edges in a placard pattern. All have five false raised bands on spine and gilt tooling, very rubbed, in the spine compartments. That all are second editions may suggest a conservative owner, who bought books only after they had received a public sign of approval by having run through an edition.

Die Vernunftlehre bears the bookplate of Arnold Mello, a merchant at 36 Fenchurch Street, London, a native of Hamburg who was naturalised as a British citizen in 1755 and who died in 1809, aged 79, on Clapham Common in Surrey and was buried in the Hamburg Lutheran Church in Trinity Lane. The mere external similarity of the volumes would suggest that the other titles also emanated from Mello, and, indeed, the three Reimarus titles comprised lots 122-124 of his 'very valuable library', which contained a noticeable amount of theology and devotional literature and was sold, together with the books of an unnamed owner,by Leigh and Sotheby in $1810 .^{7}$ The Mello catalogue was unknown to me when I wrote my former article. It shows the Reimarus titles to be just three of a large number of Mello's books - fifty-one titles in all -- to reappear in the Vye donation; clearly Mello applied his bookplate in a minority of instances. Thirty-nine of those titles are marked as having been purchased by an individual named Boetefeur, with the rest going to the London booksellers Henry Escher, John Ebers and John Bohn, with three to an unidentified 'Thornton' and one to D. Taylor. The Reimarus trio is among the Boetefeur purchase. Like the Mello family, the Boetefeurs immigrated to England from Hamburg, became London merchants, and attended the Hamburg Lutheran Church in Trinity Lane. They went into business with, and intermarried, other London merchants of Hamburg origin; Arnold Mello married Ann Boetefeur (1734-1797), and Ann's brothers John and Henry Boetefeuer and their wives were 
chosen nine times as godparents for the couple's children. ${ }^{8}$ The Mello books could have been bought by Alexander Boetefeur (d. 1869, aged 79), young as he was at the time of the sale. However, the likelier candidate for the purchaser of the books in terms of age is the London banker of Fitzroy Square Henry Boetefeur (d. 1825, aged 39). Whoever it was could conceivably have subsequently acquired books bought at the auction by booksellers. $\mathrm{Mr}$ Boetefeur did not mark the books as his. Whether the Mello-Boetefeur books then passed directly to Nathaniel Vye, or whether there is an intermediary in the provenance chain, is not clear.

Within the University of London Library the Reimarus books were kept in the same bookcase but separated within it, as shown by the early shelfmarks pencilled on the title pages: X.a.1 on Allgemeine Betrachtungen, X.b.6 on Die vornehmsten Wahrheiten, and what looks like X.b.13 on Die Vernunftlehre. Later shelving increased the separation.

Allgemeine Betrachtungen falls into the major category of the Vye donation as regards language (German), country of publication (Germany) and format (octavo). It resembles one-third of the titles in the donation by having been published in the 1760s. Although less purely devotional than the sermons and prayers in the gift, it fits well with the devotional literature through Reimarus's view of God as Creator, with particular intentions in the animal realm. ${ }^{9}$ As anticipated in my last article, its addition to the donation barely changes the general statistics of the Vye gift. Looking at books which were definitely Vye's, proportions of German and octavo titles within the Vye donation rises by less than 0.5 per cent, to 73 per cent and to 78.4 per cent respectively; the proportion of books from the decade 1761-1770 rises from 32.9 per cent to 33.8 per cent. The percentages when including books which can be inferred to have been Vye's increase by between 0.7 per cent and 1.5 per cent each, to show 77.6 per cent of his books to have been in German, 81.6 per cent to have been octavos, and 30.69 per cent to have been issued between 1761 and 1770 (as opposed to 76 per cent, 80 per cent, and 30 per cent respectively without Allgemeine Betrachtungen). The find strengthens slightly the uniformity of the donation.

The emergence of Reimarus's Allgemeine Betrachtungen means that only one of the three books I had listed tentatively in my reconstitution of the Vye gift as plausibly stemming from Vye, not two, could have been Vye's. The Mello sale catalogue contains one of the three titles (but not the others), Friedrich II's Ueber die deutsche Litteratur (Berlin: G.J. Decker, 1780; lot 335), thereby completing the contents of the University of London's first bulk book donation. 
${ }^{1}$ K.E. Attar, 'The Earliest Books at the University of London (1838): 185 Volumes Presented by Nathaniel Vye, Esq.', Library \& Information History, 32 (2016), 100-111.

${ }^{2}$ University of London Archive, UoL/ST/2/2/1, Senate Minutes, 1837-43 (1838, 'Presents').

${ }^{3}$ Catalogue of the Library of the University of London, Including the Libraries of George Grote and Augustus De Morgan (London: Taylor and Francis, 1876).

${ }^{4}$ Attar, 'The Earliest Books', p. 102.

${ }^{5}$ For a detailed discussion of Allgemeine Betrachtungen, see the scholarly apparatus in Hermann Samuel Reimarus, Allgemeine Betrachtungen über die Triebe der Thiere, hauptsächlich über ihre Kunsttriebe, 2 vols (Göttingen: Vandenhoeck \& Ruprecht, 1982). For a description, see Jonathan Israel, 'The Philosophical Context of Hermann Samuel Reimarus' Radical Biblical Criticism', in Between Philology and Radical Enlightenment: Hermann Samuel Reimarus (1694-1768) (Leiden: Brill, 2011), pp. 183-200.

${ }^{6}$ See Senate House Library, University of London, [G.S.C.] 1024 (Die vornehmsten Wahrheiten) and [G.S.C.] 1047 (Vernunftlehre).

${ }^{7}$ A Catalogue of the Entire and Very Valuable Library of the Late Arnold Mello Esq. of Clapham (among which is a Large Collection of German Literature), to which is added a Very Fine Selection of Books from a Distinguished Library... which will be Sold by Auction by Leigh and S. Sotheby ... on Thursday, May 24, 1810, and Ten Following Days ... ([London: Leigh and S. Sotheby, 1810]), p. 4.

${ }^{8}$ Margrit Schulte Beerbühl, 'The Commercial Culture of Spiritual Kinship amongst German Immigrant Merchants in London, c.1750-1830', in Commerce and Culture: Nineteenth-Century Business Elites, ed. by Robert Lee (Farnham: Ashgate, 2011), 225-54 (p. 240). I should also like to thank Nick Barratt for assistance with genealogical research on the Boetefeur family.

${ }^{9}$ Reimarus, Allgemeine Betrachtungen, leaf $* 2 \mathrm{r}$. 